\title{
COMPARISON OF THE KNOWLEDGE LEVEL OF THE 6TH CLASS STUDENTS FROM MECHANICS OF SIMPLE MASCHINES AND GEARINGS
}

\section{Gabriel BÁNESZ}

Resumé: The author compares in the article the results of the knowledge tests from the subject technical education in the 6th class. The compared results were gained from the knowledge tests from the thematic complex Simple maschines and gearings in the 5th class with the timing relationship of ten years.

Key words: technical training, knowledge tests, technical education

\section{POROVNANIE VEDOMOSTNEJ ÚROVNE ŽIAKOV 6. ROČNÍKOV Z MECHANIKY JEDNODUCHÝCH STROJOV A PREVODOV}

Resumé: Autor v článku porovnáva výsledky z vedomostných testov v predmete technická výchova v 6. ročníku. Porovnávané výsledky boli získané z vedomostných testov z tematického celku Jednoduché stroje a prevody v 6. ročníku z časovým odstupom desat' rokov.

Kl'účové slová: technická výchova, vedomostné testy, technické vzdelávanie

\section{Úvod}

V roku 1997 vstúpili do platnosti nové učebné osnovy, kde sa do osnov dostala nová téma o jednoduchých strojoch, prevodoch. V roku 1998 prebehol výskum na základných školách, ktorého ciel'om bolo zistit' vedomostnú úroveň žiakov 6. ročníkov $\mathrm{z}$ tematického celku Jednoduché stroje a prevody. Výsledky tohto výskumu boli publikované v zborníkoch vedeckých konferencií (Bánesz, 1999 s. 17, Bánesz - Lukáčová, 2000 s. 82). S odstupom desiatich rokov sme celý výskum zopakovali $\mathrm{z}$ toho dôvodu, aby sme zistili, aké zmeny nastali v úrovni vedomostí zo skúmanej oblasti. Dalo sa predpokladat, že výsledky budú lepšie ako výsledky z roku 1998. Učitelia mohli nadobudnút' lepšie skúsenosti s danou témou, zabezpečili si potrebné učebné pomôcky a pod.

Ciel'om výskumu bolo:

1. Zistit' vedomostnú úroveň žiakov z oblasti mechaniky jednoduchých strojov a prevodov na základných školách v súčasnosti rovnakými metódami, ako v roku 1998.

2. Porovnat' zistenú vedomostnú úroveň žiakov s výsledkami výskumu z roku 1998.

\section{Zabezpečenie a priebeh výskumu}

Pre splnenie ciel'a bola sformulovaná nasledovná hypotéza:

H Rozdiel medzi úrovňou vedomostí žiakov z roku 1998 a úrovňou vedomostí žiakov z roku
2008, zo základného učiva tematického celku Jednoduché stroje a prevody v 6 . ročníku, nie je štatisticky významný.

Predmetom nášho výskumu boli vedomosti žiakov vybraných ročníkov. Pomocou testu sme zist'ovali úroveň ich vedomostí zo základného učiva $\mathrm{z}$ vybraného tematického celku. Túto sme následne porovnávali s výsledkami, ktoré sme zistili v roku 1998. Predpokladali sme pritom, že rozdiel medzi úrovňou vedomostí v roku 1998 a 2008 nebude štatisticky významný.

\section{Výber vzorky}

Pri výbere vzorky sme zvolili rovnakú metodiku, akou sme postupovali v roku 1998. Čiže, nakol'ko z organizačných dôvodov nebolo možné vybrat' vzorku náhodným výberom, tak sme postupovali nasledovne, pomocou týchto stanovených kritérií:

1. Volili sme plne organizovanú školu, kde sa technická výchova vyučovala v rozsahu tak, ako to vyžadujú učebné plány a osnovy schválené MŠ SR.

2. Z takto vytipovaných škôl sme vybrali tie triedy, ktoré učil jeden učitel' a to $\mathrm{z}$ toho dôvodu, aby bola zabezpečená rovnaká kvalita a spôsob výučby vybraných žiakov.

3. Učitelia vybraných tried museli byt' kvalifikovaní, to znamená s aprobáciou pre technickú výchovu, respektíve základy techniky alebo základy priemyselnej výroby. 
4. Problematika, hlavne základné učivo, musela byt' odučená v rozsahu stanovenom učebnými osnovami.

Celkový počet respondentov bol 225, pričom stanoveným kritériám vyhovovali nasledovné školy:

\section{Rok 1998}

ZŠ Topol'ová Nitra 67 žiakov

ZŠ Andovská Nové Zámky 24 žiakov

ZŠ Tríbečská Topol’čany 37 žiakov

Spolu 128 žiakov

Rok 2008

ZŠ Topol'ová, Nitra 55 žiakov

ZŠ Brehy 10 žiakov

ZŠ Tríbečská, Topol’čany 32 žiakov

Spolu 97 žiakov

$\mathrm{Na}$ overenie vedomostí žiakov bol použitý neštandardizovaný vedomostný test. Pre jeho hodnotenie bolo použité binárne skórovanie. Pozostával z desiatich položiek, pričom každá položka bola hodnotená jedným bodom za správnu odpoved'. Respondenti mohli získat' maximálne 10 bodov. Položky $\mathrm{v}$ teste sa zameriavali výlučne na základné učivo, ktoré uvádzali učebné osnovy. Toto učivo bolo záväzné pre všetkých žiakov. Otázky testu sme zamerali na skúmanie a analýzu funkcie prevodov, konštrukciu bicykla a tiež na aplikáciu poznatkov z fyziky a iných prírodovedných predmetov $\mathrm{v}$ danom tematickom celku.

Hypotézu sme overovali pomocou Studentovho t-testu, pričom hypotézu sme považovali za platnú vtedy, ak testovacie kritérium $\mathbf{t}$ spĺn̆alo podmienky $\mathrm{t}<\mathrm{t}_{\alpha}\left(\mathrm{n}_{1}+\mathrm{n}_{2}-2\right)$ pre kritickú hodnotu testovanej hodnoty podl'a štatistických tabuliek na zvolenej hladine významnosti $\alpha$.

\section{Výsledky výskumu}

Výsledky boli spracované podl'a počtu získaných bodov $\mathrm{v}$ teste, pričom každá otázka bola hodnotená jedným bodom. Maximálny počet bodov v teste mohol byt' desat'. Výsledky sú spracované v grafe 1. Základné štatistické údaje sú pre porovnanie uvedené v tabul'ke 1 .

\begin{tabular}{|c|c|c|}
\hline roky & 1998 & 2008 \\
\hline $\begin{array}{c}\text { počet } \\
\text { respondentov }\end{array}$ & 128 & 97 \\
\hline priemer & 6,67 bodu & 5,86 bodu \\
\hline rozptyl & 4,80 bodu & 3,29 bodu \\
\hline $\begin{array}{c}\text { smerodajná } \\
\text { odchýlka }\end{array}$ & 2,19 bodu & 1,81 bodu \\
\hline
\end{tabular}

Tabul'ka 1: Základné štatistické údaje výskumu
Testovacie kritérium $\mathrm{t}$ vypočítané $\mathrm{z}$ počtu získaných bodov bolo $\mathrm{t}=2,98$, počet stupňov vol'nosti $\gamma=223$. Pri zvolenej hladine významnosti $\alpha=0,05$ bola kritická hodnota testovacieho kritéria $\mathrm{t}_{0,05}=1,64$. Nakol'ko pre nulovú hypotézu platí $\mathrm{t}<\mathrm{t}_{0,05}$ tak túto nemôžeme prijat'. Znamená to, že žiaci testovaní v roku 2008 nedosiahli rovnaký výkon, ako žiaci $\mathrm{v}$ roku 1998. Výkon žiakov vo vedomostných testoch v roku 20088 nepreukázal zlepšenie oproti roku 1998.

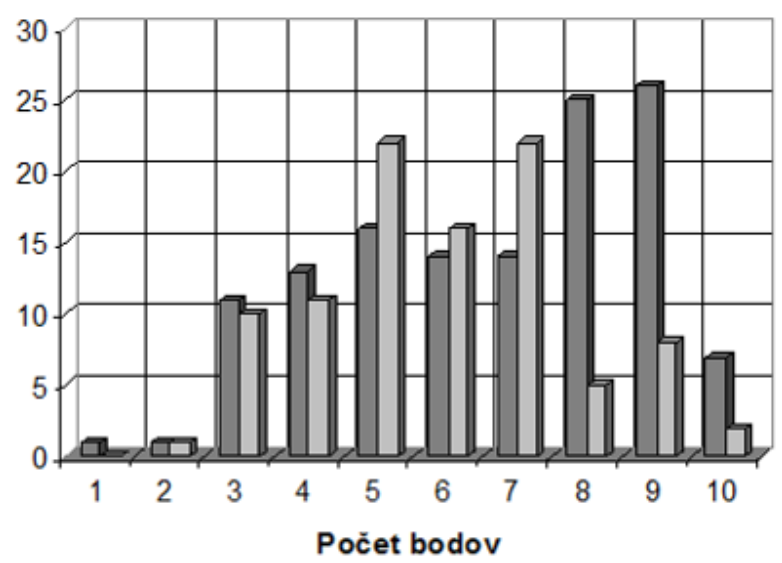

1998 Graf 1 Porovnanie výsledkov podl’a 口2008 počtu získaných bobov

\section{Záver}

Nami stanovenú hypotézu sme zamietli. Napokon aj ked' zoberieme do úvahy základné štatistické ukazovatele, tak nastal pokles vo výkone žiakov za sledované obdobie. Aritmetický priemer klesol z hodnoty 6,67 bodu na hodnotu 5,86 bodu.

Kde hl'adat' príčinu takéhoto výsledku? Podl'a nášho názoru príčin môže byt' hned' niekol'ko. V prvom rade si treba uvedomit', že stále platí tzv. Usmernenie MŠ, ktoré umožňuje do alternatívneho učiva technickej výchovy začlenit' pestovatel'ské práce, prípadne rodinnú prípravu. Zložka technická výchova sa tým pádom redukuje na úroveň trinástich hodín za školský rok.

Pre potvrdenie tejto skúsenosti uvádzame aj výsledky prieskumu, ktorý realizoval Pavelka z Prešovskej univerzity, ktorý uvádza, že existujú napríklad školy, kde sa predmet technická výchova prakticky nevyučuje (Pavelka 1999 s. 28).

Za pozornost' stojí aj zloženie učitel'ov technickej výchovy podl'a pedagogickej praxe. Výskum v tomto smere uskutočnila Lukáčová 
(Lukáčová, 2008 s. 159). Vyplýva z neho, že chýbajú učitelia práve s praxou od 16 do 20 rokov. Za sledované obdobie sme pri príprave učitel'ov technickej výchovy nezaznamenali pokles záujmu o štúdium, napriek tomu z praxe odišlo v rovnakom období najviac učitel'ov.

Ak zoberieme d'alej do úvahy, že tematické celky s mechanikou vstúpili do platnosti pred dvanástimi rokmi (išlo ešte o progresívny variant osnov z roku 1995) tak do praxe nastupovala práve skupina učitel'ov, ktorí majú v dížke pedagogickej praxe najmenšie zastúpenie. Takýmto spôsobom nám chýba $\mathrm{v}$ súčasnosti práve silná generácia učitel'ov technickej výchovy, s priemernou praxou okolo 15 rokov.

Ako skvalitnit' vyučovací proces tak, aby sme v skúmanej oblasti dosiahli lepšie výsledky? $\mathrm{V}$ tomto smere už $\mathrm{v}$ minulom období bolo uskutočnených niekol'ko pedagogických experimentov s preukázatel'ne lepšími výsledkami (Lukáčová, 2007 s. 106 , Raczyńska 2005 s. 192, Stebila - Duriš, 2008 s. 472, Sałata, 2001 s. 156, Tomková, 2006 s. 179). Išlo o experimenty, v ktorých sa využívali špeciálne vyučovacie metódy ako: problémové vyučovanie, brainstorming, metóda čiernej skrinky, systém vzdelávania mastery learning a pod.

V máji 2008 vstúpila do platnosti Školská reforma. Od nového školského roka 2008/2009 bola zavedená do prvých ročníkov základných a stredných škôl a aj do piateho ročníka základnej školy.

Je na škodu veci, že do štátneho vzdelávacieho programu sa predmet technika (technická výchova) dostal v tak malom rozsahu. Pol hodina týždenne $\mathrm{v}$ siedmom a ôsmom ročníku je žalostne málo. Uvedomujeme si, že nie je možné počty hodín hnat' do vel'kých počtov. No aj tak tento premet by mal mat' zastúpenie minimálne $\mathrm{v}$ každom ročníku druhého stupňa základnej školy v počte jedna hodina týždenne. Dôvod je vel'mi jednoduchý! Záujem absolventov základných škôl o odborné vzdelávanie klesá! Pri takom intenzívnom rozvoji priemyslu v Slovenskej republike nebude mat' v ňom (obávame sa že už nemá) kto pracovat'.

\section{Literatúra}

BÁNESZ, G.: Analýza osnov technickej výchovy v 6. ročníku z aspektu princípov a systémov v technike. In: Zborník. Vplyv technickej výchovy na rozvoj osobnosti žiaka. Nitra: PF UKF, 1999. s. 17 - 20. ISBN 80-8050-370-2

BÁNESZ, G. - LUKÁČOVÁ, D.: Vedomostná úroveň žiakov 6. ročníka z pohl'adu princípov a systémov v technike. In: Zborník Technické vzdelávanie ako súčast' všeobecného vzdelania. Banská Bystrica: FPV UMB v Banskej Bystrici, 2000. s. 81 - 83 ISBN 80-8055-292-4

LUKÁČOVÁ, D.: K problematike vytvárania kompetencií $\quad \mathrm{v}$ pregraduálnej a postgraduálnej príprave učitel'ov technickej výchovy. In. Monografie z mezinárodní konference. Trendy ve vzdělávání. Informační technologie a tecnické vzdélávání. Olomouc: UP, 2008. ISBN 978-807220-311-6 s. 159

LUKÁČOVÁ, D.: Zvýšenie efektívnosti vyučovacieho procesu v technickej výchove prostredníctvom štandardov. In. e-pedagogium : Nezavislý odborný časopis určený pedagogickým pracovniků všech typu škol. - ISSN 1213-7758. Roč. 2007, č. 2 (2007), s. 106.

PAVELKA, J.: Vyučovacie prostriedky v technickej výchove. s. 28 Prešov: FHPV PU, 1999. ISBN 80-88722-68-3

RACZYŃSKA, M.: Internet $w$ szkole $w$ świetle badań gimnazjów regionu radomskiego. Politechnika Radomska 2005, s.192, ISDN 16425278

SAŁATA E.: Metoda projektów - klucz do nauczania techniki. W: Trendy technicznego vzdelani red. J.Steigla, Olomouci 2001, ISBN 80244-0287-4, pp. 156

STEBILA, J. - ĎURIŠ, M.: Overenie úspešnosti použitia MUP $v$ edukačnom procese. In. Monografie z mezinárodní konference. Trendy ve vzdělávání. Informační technologie a tecnické vzdělávání. Olomouc: UP, 2008. ISBN 978-807220-311-6 s. 472

TOMKOVÁ, V.: Grafické vyjadrovanie žiakov základných škôl. In Trendy ve vzdelávaní 2006. Edukační technológie a inovace technického vzdélávání. Olomouc: VOTOBIA Olomouc, 2006, s. 178-181. ISBN 80-7220-260-X.

doc. PaedDr. Gabriel Bánesz, PhD.

Katedra techniky a informačných technológií

PF UKF v Nitre

Dražovská 4, 94974 Nitra

$+421907670234$

gbanesz@ukf.sk 